\title{
MOOD UNDERSTAND RECALL DIGEST EXPAND AND REVIEW STRATEGY FOR STUDENTS' READING COMPREHENSION
}

\author{
Herlina Daddi, Dewi Susilawati, Andi Tenri Ampa,
}

English Education Department, Faculty of Teacher Training and Education

Universitas Muhammadiyah Makassar

Amiruddin

English Education Department, STKIP YPUP

herlinadaddi@unismuh.ac.id

\begin{abstract}
This research aimed to explain the improvement of the students' reading comprehension in terms of literal comprehension dealing with main ideas and sequence details and interpretive comprehension dealing with prediction outcomes and conclusion. To explain the improvement, the researcher used a classroom action research (CAR) which was conducted in two cycles in which every cycle consisted of four meetings. The location of this research was taken at the ninth grade students of SMP Muhammadiyah 5 Mariso, Makassar with a number of the subject were 36 students. The research findings indicated that the implementation of Mood Understand Recall Digest Expand and Review (MURDER) Strategy was improved the students' reading comprehension in terms of literal comprehension and interpretive comprehension. It was proved by the mean score of cycle I was 64.31. It was classified as fair then improved to be 71.20. It was classified as fairly good in cycle II. They are higher than the mean score of diagnostic test 52.21 that classified as poor. Therefore there was improvement of the students' reading comprehension in terms of literal comprehension dealing with main ideas and sequence of details and interpretive comprehension dealing with prediction of outcomes and conclusion.
\end{abstract}

Keywords: Reading Comprehension, Mood Understand Recall Digest Expand and Review Strategy (MURDER)

\section{INTRODUCTION}

The goals of teaching English in Indonesia are mainly to enable the students to use English for communication and to read books and references written in English. The students are expected to have skills of the English language such as reading, writing, listening, speaking, and other elements of language that must be taught to the students through the chosen themes. Among the four skills above, reading get greater attention than three others, because reading is one of the important skills. Reading can be defined as an active 
cognitive process of interacting with the print and monitoring comprehension to establish meaning and through reading we can get much knowledge, study new words, comprehend ideas, study the word are used, how to implement the grammatical rules, and gain the information.

Teaching reading to students requires many different techniques to avoid boredom and invite students' interest. Of all techniques, which have been studied earlier such as scanning technique, skimming technique and detailed reading, none is referred as the most effective one (Sangkala, 2014)

Problem mostly occurs to the students when reading book. Sometimes students were facing a book but do not read at all. They just can mention symbol word without getting any idea from the book. The researcher her self-experienced when reading a book without any comprehension tends to feel sleepy. As the explanation above, the data from observation indicates that the students of SMP Muhammadiyah 5 Mariso Makassar VIII Class and also face the same problems. Most of them are not competent to comprehend English text well. Many students can read the word in passage perfectly but are unable to answer the questions. They can say the words, but unable to gain the meaning from words. They find hard to comprehend reading materials.

The writer also observed that the teacher only asked the students to read, and then they must answer the question without giving explanation about the text first. So the students who did not understand what they read. As a result, they could not answer the whole questions correctly. Based on the result of students' achievement in reading are still underneath, it is about 5.5 mean score and the target score is (70.00). In this case, the students have to read critically, and the teacher must select the suitable technique or strategy in teaching and learning.

What a teacher has to consider as a prime important task is how to design the reading course with strategies and techniques to lead the students to comprehend the concept from the author's mind in the text. There have been a lot of techniques and strategies discussed by many experts dealing with reading comprehension. One of the strategies to be offered here is Murder Strategy. In which the students are learning how to interact with the text they read. By using 
murder strategy, the students' offers many possible explanations based on cognitive psychology that gives guidance to the reader to enhance their learning. For example; recalling stage, detecting, elaborating, and reviewing the password associated with giving a lot of text for dyad members must be stated in the form of verbal, description, development, and summarizes the ideas - the main idea of the text.

Good readers use what they know about language and the word to interact with what they are reading. This helps them create meaning from the words on the page. Because the important comprehending text, the researcher offers the use of Mood, Understand, Recall, Digest, Expand, and Review (Murder) Strategy in teaching reading, because it can motivate students to read more and it can bring the students to interact with text.

\section{Sustained Theory of Mood, Understand, Recall, Digest, Expand, and Review (Murder) Strategy}

A theory and research that has important implications for the training of learning ability is Sternberg's work. He has developed a logic and methodology for isolating component thinking processes that underlie certain task domainssolving the types of analogies that appear on standardized IQ tests. He also has suggested guidelines for design of process-oriented training to improve the speed and facility with which learners carry out basic thinking operations (Sternberg, 1983). Sternberg's perspective on training departs from Gagne's instructional theory.

According to the Sternberg model, the purpose of "Intellectual skills training" is not to develop intellectual skills as Gagne would define them, but to improve the general processing intelligence of the learner. To Sternberg, an intellectual skill is a chronometric series of discrete cognitive processes, including lower and higher processes. He does not draw a clear-cut distinction between training an intellectual skill itself and developing the processing capability that operates with or upon that knowledge. Sternberg's research indicates that intelligence-improvement programs should offer at least three types of training: micro-component, macro-component, and meta-component training. 
Micro component training. This type of training directly and separately focuses on specific information-processing sub skills that underlie whatever learning tasks the student eventually must perform. These include what Newell and Simon (1972:19) have called "elementary information processes". An example of micro component sub skill involved in reading would be letter-group perception speed. Another example of a micro component necessary for performance of mathematical computations is recall of number facts from longterm memory.

Macro component training. A second goal of intelligence training designed according to Sternberg's theory is to facilitate development of relatively complex processing systems designated as macro components. These are groups of component processes that frequently are chunked and thus can be viewed as one holistic skill. Examples of macro components related to learning strategies include note taking and outlining skills. Macro components almost exactly parallel Gagne's description of intellectual skills. Schools have successfully taught many types of macro components for years, and there is reason to suspect that these same technologies would work as well for any learning skill that can be subjected to task analysis.

Meta-component training. A third goal of intelligence training, according to the Sternberg guidelines, is to engineer an executive control mechanism that flexibly and rapidly responds to problem-solving situations by mobilizing and organizing relevant micro and macro components. Sternberg has argue that programs attempting to train a form of intelligence "should provide explicit training in both executive and nonexecutive information processing, as well as interactions between the two kinds" (Sternberg, 1983).

The Metastrategy approach that has been used in teaching and learning strategies involves teaching students to use domain-general heuristic planning models, or "metastrategies" (Dansereau, 1978). For example, Dansereau and his associates have taught students to use MURDER, a mnemonic which stands for a sequence of steps in a general study strategy: set your Mood, read for Understanding, Recall, Digest information (correct recall, amplify and store), 
Expand knowledge through self-inquiry, and Review mistakes. Specify study skills associated with each metastrategy step also are taught: Mood-setting may involve positive self-talk and progressive relaxation; amplification could be accomplished through imaging or paraphrasing, and so on. The relationship between Dansereau's metastrategy and its related subskills parallels Sternberg's (1983) recommended link between executive and nonexecutive informationprocessing routines.

\section{RESEARCH METHODOLOGY}

This research followed the principal working of classroom action research (CAR) that contained of four stages; they are: Planning, Implementation of Action, Observation, and Reflection. In this classroom action research will be conducted through two cycles to observe the students' competent in reading comprehension through MURDER Strategy. After finding the result of the cycle I, the researcher will continue to cycle II to improve the result in students' competence in reading comprehension through Mood Understand Recall Digest Expand and Review Strategy. In addition, the following variables of the research are:

1. Independent variable

Independent variable of the research is Mood Understand Recall Digest Expand and Review (MURDER) Strategy in teaching reading comprehension. MURDER is strategy to be used to comprehend the information contained in reading materials.

2. Dependent variables

Dependent variables are the students' literal reading comprehension and interpretive reading comprehension.

With the indicators are:

1. The indicators of literal reading comprehension are the main ideas and sequence of details.

2. The indicators of interpretative comprehension are conclusion and prediction of outcomes. 
The research subject in this action classroom research is students of VIII class SMP Muhammadiyah 5 Mariso Makassar that consists of 36 students. Based on the paradigm of classroom action research, there are two main instruments which used to collect data; they are observation list and reading test result. The functions of each research are:

1. The observation is to watch out the situation of teaching and learning;

2. Reading test result is used to know the concept of understanding achievement and mastering material after following learning activity.

\section{DISCUSSION}

The results of the data findings found that teaching reading comprehension through Mood, Understand, Recall, Digest, Expand, Review (MURDER) Strategy can improve the students' achievement to identify literal and interpretative of reading. In the further interpretation of the data analysis were given below:

\section{The Improvement of the Students' in Literal and Interpretative Comprehension}

The improvement of the students' literal comprehension, which focused on main ideas and sequence of details as indicators and interpretative comprehension which focused on prediction outcome and conclusion as indicators in X class of SMP Muhammadiyah 5 Mariso Makassar as result of the students' assessment of Diagnostic-Test, cycle I can be seen clearly in the following table: 
Table 1. The Improvement of the Students' Reading Comprehension among Diagnostic Test to Cycle 1

\begin{tabular}{llll}
\hline Indicators & \multicolumn{2}{l}{ Students' Score } & Improvement \\
\cline { 2 - 4 } & Diagnostic-test & Cycle 1 & $\begin{array}{l}\text { D-T } \Rightarrow \mathbf{C 1} \\
(\%)\end{array}$ \\
\hline Main idea & 45.97 & 57.91 & $11.94 \%$ \\
\hline Sequence details & 50.41 & 60.05 & $9.64 \%$ \\
\hline Prediction outcome & 57.22 & 68.05 & $10.83 \%$ \\
\hline Conclusion & 55.27 & 71.25 & $15.98 \%$ \\
\hline \multicolumn{1}{c}{$\mathbf{x}$} & 208.87 & 257.26 & $48.39 \%$ \\
\hline$\overline{\mathbf{X}}$ & 52.21 & 64.31 & $12.1 \%$ \\
\hline
\end{tabular}

The data on the table above shows the students' reading comprehension score in literal and interpretative comprehension. Before implementing of Mood, Understand, Recall, Digest, Review (M.U.R.D.E.R) strategy the diagnostic-test of the four indicators above are poor (52.21) where students' mean score of literal comprehension which focused on main idea (49.57), sequence details (50.41) whereas students' mean score of interpretative comprehension which focused on prediction outcome (57.22) and conclusion (55.72), after implementing of M.U.R.D.E.R strategy in cycle 1, the result had few improved (64.31) it was greater than the diagnostic-test. Where the students' mean score of main idea (57.91), students' sequence details (60.05) whereas students' prediction outcome (68.05) and the last improvement of students' determines conclusion (71.25).

The table above indicates that there is improvement of the students' in literal and interpretative comprehension from diagnostic-test to cycle 1 $(52.21<64.31)$ so the improvement of the students' achievement from diagnostic-test to cycle 1 is $12.1 \%$. Based on the data of the table above, it was also classified in fair. Therefore the target can be achieved by being continued in cycle 2 with revision of the plan lesson and teaching material. 
The result of the students' improvement can be shown as the following graphic:

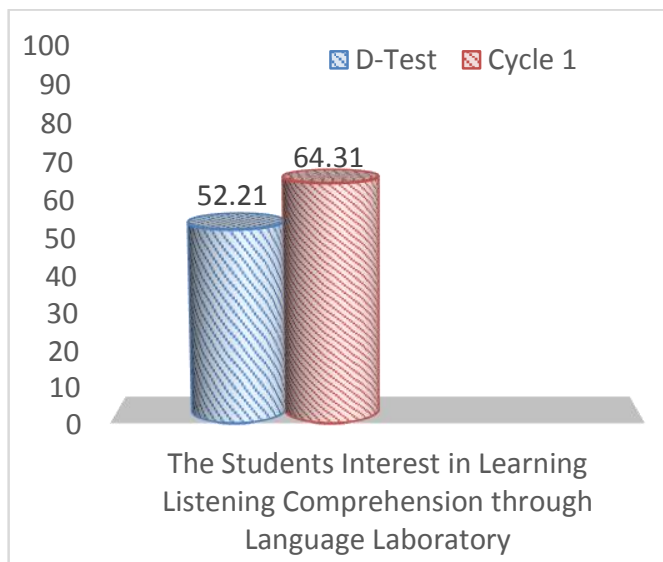

Figure 1. The Improvement of the Students' From Diagnostic Test to Cycle 1

The figure above shows that the score of diagnostic-test (52.21) was fewer than cycle 1 (64.31). This means that there is improvement, even though it was still classified as fair. This means also the target in cycle 1 (75) has not been achieved yet.

\section{The Classification and Percentage of the Students' Achievement Literal and Interpretative Comprehension.}

Table 2. The Classification and Percentage of the Students' Reading Comprehension among Diagnostic Test to Cycle 1

\section{$\begin{array}{lllll}\text { Classification } & \text { Scores } & \text { D. Test } & \text { Cycle } 1 & \text { Improvement }\end{array}$}

\begin{tabular}{lllllll}
\cline { 3 - 6 } & & $\mathbf{F q}$ & $\mathbf{\%}$ & $\mathbf{F q}$ & $\mathbf{\%}$ & \% \\
\hline Excellent & $96-100$ & - & - & - & - & - \\
\hline Very good & $86-95$ & - & - & - & - & - \\
\hline Good & $76-85$ & - & - & - & - & - \\
\hline Fairly good & $66-75$ & - & - & 13 & $36.11 \%$ & $36.11 \%$ \\
\hline Fair & $56-65$ & 6 & $16.66 \%$ & 21 & $58.33 \%$ & $41.67 \%$ \\
\hline Poor & $36-55$ & 30 & $83.33 \%$ & 2 & $5.55 \%$ & - \\
\hline Very poor & $0-35$ & - & - & - & - & - \\
\hline Total & & $\mathbf{3 6}$ & $\mathbf{1 0 0}$ & $\mathbf{3 6}$ & $\mathbf{1 0 0}$ & $\mathbf{7 7 . 7 8 \%}$ \\
\hline
\end{tabular}

The classification and percentage of the students' can be shown as the following graphic: 


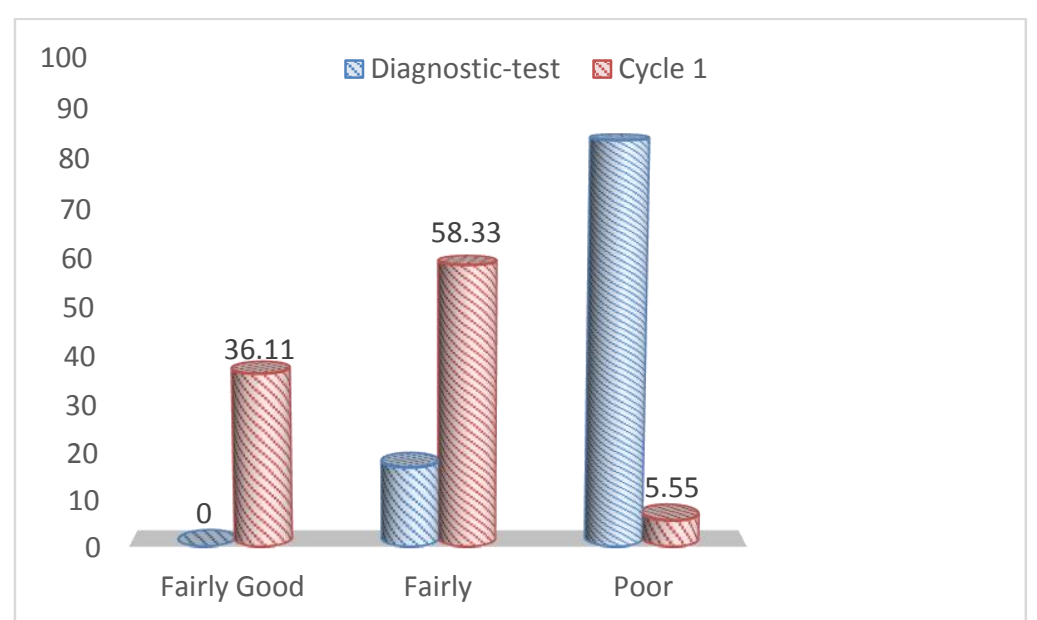

Figure 2. The Classification and Percentage of the Students' From Diagnostic Test to Cycle 1.

The table and chart above indicates that the effectiveness of the students' literal and interpretative comprehension through mood, understand, recall, digest, expand, and review (M.U.R.D.E.R) Strategy was still fair. It is identified by the classification of the students in which no students got very poor and only 2 or $(5.55 \%)$ students got poor score in cycle 1. After the applying this strategy (36.11\%) of the students are classified fairly good and (58.33\%) students meaning of them are classified fair in cycle 1 .

\section{The Result of the Students' Activeness in Teaching and Learning} Process

The observation result of the students' activeness in teaching and learning process toward the implementation of Mood, Understand, Recall, Digest, Expand, and Review (MURDER) Strategy in improving the students' reading comprehension at the third grade students of SMP Muhammadiyah 5 Mariso Makassar which is conducted in 2 cycles during 8 meetings is taken by the observer through observation sheet.

The result above is formulated based on the technique of data analysis and the students' scores that are collected through observation sheet. From the table above shows that in cycle I the students' activeness in each meeting improved. It can be seen clearly in table that the students' 
activeness in the fourth meeting is higher than the first, the second and the third meeting, where the first meeting in cycle I the students' activeness is $42.36 \%$ and it improves to $44.02 \%$ in the second meeting, and then students' activeness in the third meeting is $61.11 \%$ improves to $72.91 \%$ in the fourth meeting, So the average of the students' activeness in cycle I is $55.10 \%$.

In cycle II the improvement of the students' activeness improves significantly. Where in the first meeting in cycle II the students' activeness is $64.58 \%$ improves to $70.13 \%$ in the second meeting. In the third meeting in cycle II the students' activeness improves normally to $77.77 \%$, and then in the fourth meeting the students' activeness improves to $86.80 \%$. This is caused by the teaching material is really interesting for the students and the teacher gives them game when opens the class. So the average of the students' activeness in cycle II is $74.83 \%$. Later, the result is presented in the chart below that shows the average of student' activeness in the first cycle and the second cycle.

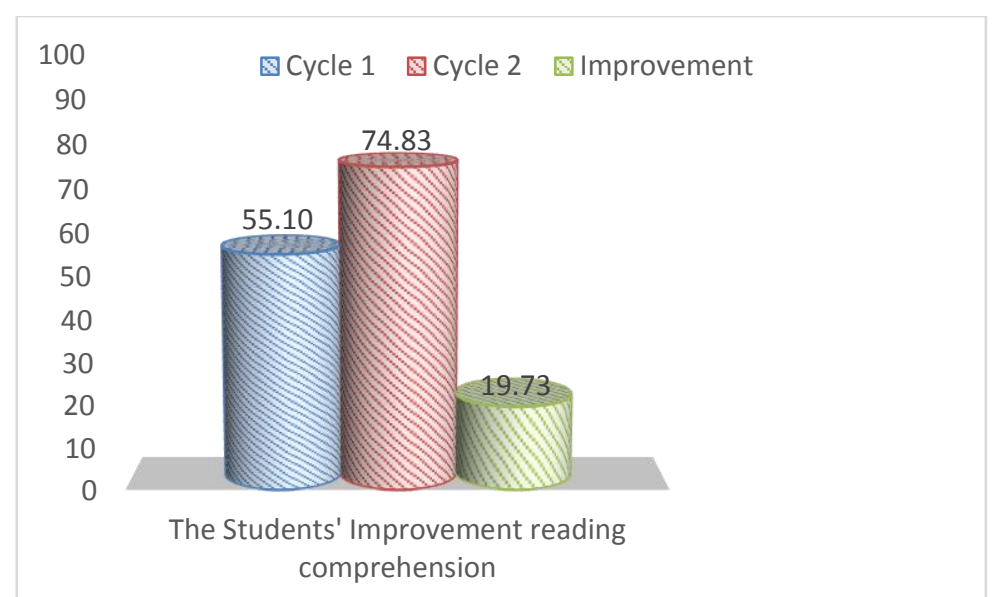

Figure 4. The Observation Result of the Students' Activeness in Learning Process.

The chart above shows that there is improvement of students' activeness in teaching and learning process where in cycle $\mathrm{I}$ is $(55.10 \%)$ lower than cycle II, but after conducting cycle II the students' activeness in learning process becomes $74.83 \%$. $(55.10<74.83)$. The improvement of students' activeness is $19.73 \%$. 


\section{The Classification and Percentage of the Students' Achievement Literal and Interpretative Comprehension.}

The table above shows the classification and percentage of the students' reading comprehension start at diagnostic test indicates that 6 students $(16.66 \%)$ get fair, 30 students $(83.33 \%)$ get poor, and none of students for the other classification.

After taking an action in cycle I by implementing M.U.R.D.E.R strategy, the percentage of the students' 13 students $(36.11 \%)$ get fairly good, 21 students $(58.33 \%)$ get fair, and 2 students $(5.55 \%)$ get poor and none of the students for the other classification.

To know the percentage of the students' achievement clearly, following chart is presented:

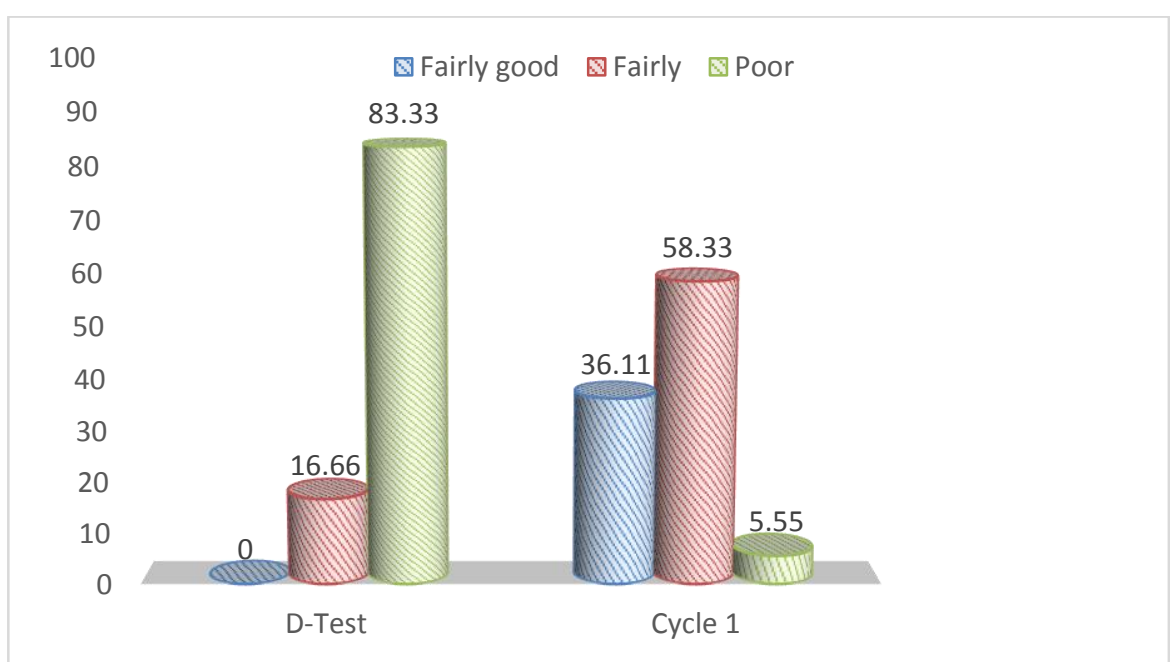

Figure 5. The Classification and Percentage of the Students' Reading Comprehension Start at Diagnostic Test to Cycle 1.

The chart above shows the result of the students' in interpretative and literal comprehension. After applying the M.U.R.D.E.R strategy in cycle I, the result of students' achievement improved where Cycle 1 is higher than Diagnostic Test. The students' achievement in Diagnostic Test is $83.33 \%$ categorized as poor, $16.66 \%$ categorized as fairly, and none of students categorized fairly good. While in cycle 1 the students achievement only 
$5.55 \%$ categorized as poor, $58.33 \%$ categorized as fairly and $36.11 \%$ categorized as fairly good.

The table above shows the classification and percentage of the students' reading comprehension start at cycle 1 indicates that 13 students (36.11\%) get fairly good, 21 students $(58.33 \%)$ get fair, 2 students $(5.55 \%)$ get poor and none of students get for the very poor classification.

After taking an action in cycle II by implementing M.U.R.D.E.R strategy, the percentage of the students' 4 students (11.11\%) get good, 28 students $(77.77 \%)$ get fairly good, 4 students $(11.11 \%)$ get fair and none of the students get for very poor.

To know the percentage of the students' achievement clearly, following chart is presented:

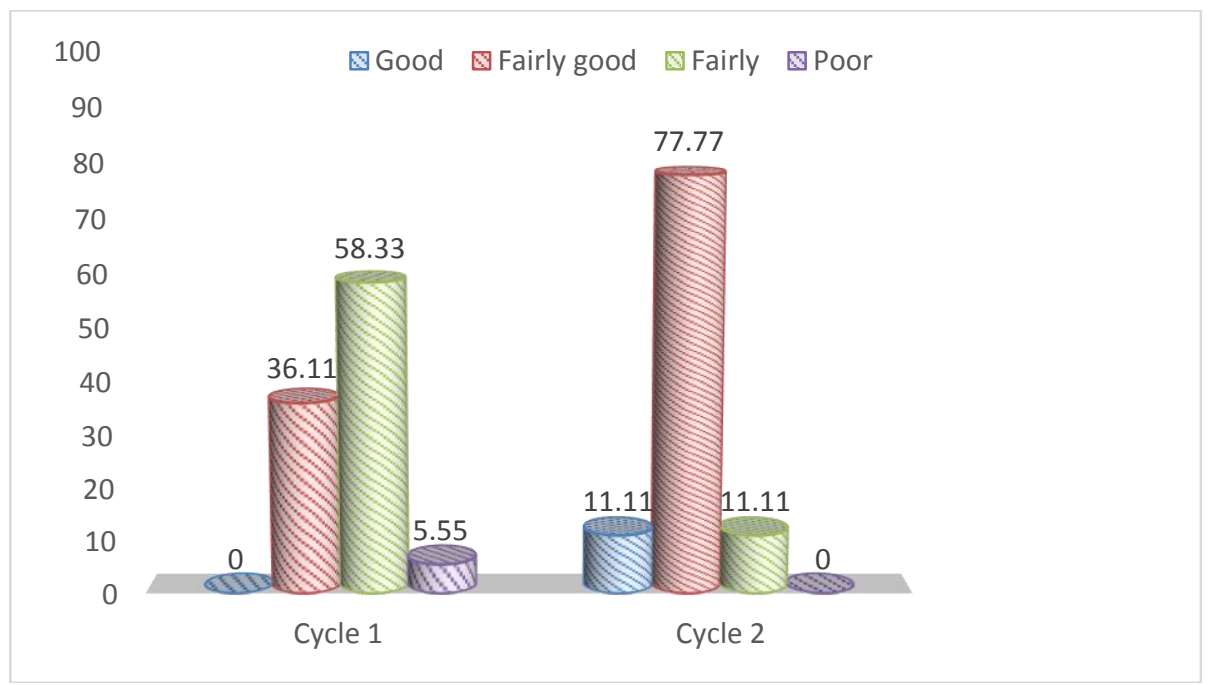

Figure 6. The Classification and Percentage of the Students' Reading Comprehension Start at Cycle 1 to Cycle 2

The chart above shows the result of the students' in interpretative and literal comprehension. Continuing the M.U.R.D.E.R strategy in cycle II, the result of students' achievement improved where cycle II is higher than cycle I. The students' achievement in cycle I is $5.55 \%$ categorized as poor, $58.33 \%$ categorized as fair, and $36.11 \%$ categorized as fairly good but none of students categorized good. While in cycle II the students' achievement 
none of students categorized as poor, $11.11 \%$ categorized as fair, $77.77 \%$ categorized as fairly good and $11.11 \%$ students categorized as good.

\section{CONCLUSION}

Based on the research findings and discussions in the previous chapter, the following conclusions are presented:

1. The implementation of Mood, Understand, Recall, Digest, Expand, and Review (MURDER) strategy in presenting the reading comprehension material at the IX class students of SMP Muhammadiyah 5 Mariso, Makassar improves the students' achievement. The findings indicate that the mean score of the students' reading comprehension in terms of literal comprehension dealing with the main ideas and sequence details and interpretive reading comprehension dealing with prediction outcomes and conclusion in cycle II is higher than the mean score of test in cycle I (71.20>64.31) and the improvement of reading comprehension is $8.63 \%$.

2. The implementation of Mood, Understand, Recall, Digest, Expand, and Review (MURDER) strategy was able to improve the students' literal comprehension at the students of IX class of SMP Muhammadiyah 5 Mariso, Makassar.

3. The implementation of Mood, Understand, Recall, Digest, Expand, and Review (MURDER) strategy was able to improve the students' interpretive comprehension at the students of IX class of SMP Muhammadiyah 5 Mariso, Makassar.

4. Mood, Understand, Recall, Digest, Expand, and Review (MURDER) strategy could increase the students learning achievement, the students' involvement and interaction as well as the learning atmosphere. 


\section{BIBLIOGRAPHY}

Abbott, Gerry, Greenwood, John, Mckeating Douglas: Wingard Peter 1981, the Teaching of English as an International Language: A Practice Guide. Great Britain Biddels Ltd.

Alexander, A. 1998 Teaching Reading (www. Nclrc. Org/reading/reindex). Retrieved on October 20, 2009.

Allington and Cunningham. 1996. Sustained Silent Reading program. Available on the internet. http://www.yahoo.com.

Arikunto, S., Suhardjono., Supardi. 2009. Penelitian Tindakan Kelas. Bumi Aksara: Bandung.

Baker, L., \& Brown, A.L (1984). Metacognitive skills and reading. In D. Pearson, R. Barr, M. Kamil, \& P. Mosenthal (Eds), Handbook of reading research. New York: Longman.

Bower, G.H., \& Reitman, J.S. (1972). Mnemonic elaboration in multi-list learning. Journal of verbal learning and verbal behavior, 11, 478-485.

Cranken. M. C. 1971. Evaluating Sustained Silent Reading in Reading Class. Hong Kong, China: http//itselj.org/articles/chow.SSR, html.

Carillo. (1976: 1) Teaching Reading London. London: Second Edition USA: Addition Prentice.

Dansereau, D.F (1978). The development of a learning strategy curriculum. In H.D. O’Neill, Jr. (Ed), Learning Strategies. New York: Academic Press.

Frey, Edward (1981) "Teaching Faster Reading" A manual Cambridge. Cambridge: University Press. 
Flavel, J.H. (1979). Metacognition and Cognitive Monitoring: A new area of psychological inquiry. American psychologist, 34, 906-911.

Gloria Simanjuntak, Edithia, Dra. Developing Reading Skill for EFL Students. Jakarta: .Departemen Pendidikan dan Kebudayaan.

Gagne, R. M., \& Dick, W. (1962). Learning measures in a self-instructional program in solving equations. Psychological Reports, 10, 131-146.

Harris, J. Albert, at al. 1980. How to Increase Reading Ability. New York: Harper Collins publisher.

Herman Anderson, Pearson, and Naggy. 1987. Sustained Silent Reading. Available on the internet. http://www.yahoo.com.

Hornby, A. S. 1994. Oxford Advanced Learner's Dictionary of Current English. Fourth Edition. Oxford: oxford University Press.

Jim Tre lease. Sustained Silent Reading program. Available on the internet. http://www.yahoo.com

Newell, A., \& Simon, H.A. (1972). Human problem solving. Englewood Cliffs, NJ: Prentice-Hall.

Nuttal, Christine, 1982. Teaching Reading Techniques in a Foreign Language. London: Heinemann education Books. Organization, and practice. Massachusetts: Newbury House Publisher, Inc.

Sangkala, I. (2014). Wondershare Quiz Creator Software Improves Students' Reading Comprehension. JKIP, 1(2), 93-101.

Smith, at al. 1980. Reading Instruction for today children. U.S: Prentice Hall. Inc. 
Sternberg, R.J. (1977), Intelligence, Information Processing and Analogical Reasoning: The componential analysis of human abilities. Hillsdale, NJ: Erlbaum.

Sternberg, R.J., Ketron, J.L., \& Powell, J.S. (1982). Componential approaches to the training of intelligent performance. In D.K. Detterman \& R.J Sternberg (Eds), how and how much can intelligence be increased. Norwood, NJ: ABLEX.

Tulving, E., \& Psotka, J. (1971). Retroactive Inhibition in free recall: Inaccessibility of information available in the memory store. Journal of experimental psychology, 87, 1-8. 